\title{
GEOLOGY
}

UDC 622.324 .5

R. K. Kamarov, Cand. Sc. (Tech.), Prof.,

N. M. Zamaliyev,

D. R. Akhmatnurov,

R. A. Musin

\section{SETTING THE VOLUME AND LOCATION OF THE GAS COLLECTORS OF ABANDONED COAL MINES}

Purpose. Developing a research method for setting the most probable gas collector cavities and their volumes from the position of rock movement and gas dynamics of coal seams.

Methodology. The model of forming voids and cracks filled with gas in the abandoned mines is based on the analysis of mining-and-geological and mining-technical conditions, as well as the existing ideas of the mechanism of rock movement in the mined-out space of coal mines.

Findings. As a result of the analysis of the mechanism of shifting the underworked and overworked coal seams, there have been established the most probable locations of the gas collectors from the position of its possible extraction in the abandoned mines. There has been proposed a model for calculating the volume of gas cavities after the mine liquidation. There has been determined a fraction of voidness with respect to the extracted coal that makes about $8 \%$.

Originality. Ensuring the methane extraction from the abandoned mines by drilling vertical wells from the surface is associated with solving the task of determining their location based on the calculation of the intersection of the most likely gas collectors. The model of forming voids and cracks filled with gas in the abandoned mines has been constructed on the basis of analyzing the regularities characterizing the process of rock movement in the course of stoping in conjunction with the changing parameters of the gas dynamics of coal seams.

Practical value. The obtained results are the basis for developing a feasibility study for utilizing methane from the abandoned mines which will involve large resources of the new energy carrier in the fuel-and-energy balance of the region and improve the environmental situation by reducing methane emissions into the atmosphere.

Keywords: methane, abandoned reserves, desorption, gas collectors, methane recovery, industrial use

Introduction. The development of the real sector of the economy in Kazakhstan will require a large-scale increase in the extraction of energy resources, and an important role in this will belong to coal energy. At present significant mineral resources are lost in the subsoil owing to the technical and economic inexpediency of their development in complicated mining and geological conditions. So, in the Karaganda coal basin, offbalance reserves of coal make up over 16 billion tons, the left reserves for the abandoned mines exceed 900 million tons.

With the large-scale closure of unprofitable mines in the Karaganda basin the most gas-intensive mines in the Industrial and Saran fields with about 1.6 billion cubic meters of methane concentrated were liquidated.

According to the data of the Karagandagiproshaht Institute, in the fields of 10 abandoned mines of the Industrial unit on the $K_{10}$ and $K_{12}$ seams in the pillars under the shafts there were left about 194 million tons of coal (138 million tons in $K_{12}, 56$ million tons in $K_{10}$ ), of

(C) Kamarov R. K., Zamaliyev N. M., Akhmatnurov D. R., Musin R. A., 2018 them $41 \%$ are coal reserves in the pillars under the shafts and decommissioned reserves, $32 \%$ or 62.5 million tons of coal are concentrated in the area of the stoping. In the field of the abandoned mine named after the $50^{\text {th }}$ anniversary of the October Revolution only in the safety pillars there are contained more than 60 million tons of coal, of which about 9 million tons under the mine workings, in the area of stoping on the $K_{10}$ and $K_{12}$ seams the operating losses amount to more than 33 million tons of coal.

Over time, the isolated volumes of completely abandoned mines in which there is no active ventilation become gas collectors containing large volumes of the methane-air mixture, from which methane under pressure penetrates to the surface developing a threat of emergencies.

The carried out scientific and experimental studies for determining methane volumes, places of its probable accumulation in the abandoned mines, made it possible to conclude that it is necessary to utilize methane for industrial and domestic needs, as well as to reduce atmospheric pollution by greenhouse gas. The work to re- 
duce methane emissions could make significant changes in the degree of the climate change in the future.

Determining the unsolved problem. In recent years, in connection with the growing interest in the problem of coal methane, a number of researchers have drawn attention to the abandoned and liquidated coal mines as sources of methane emissions into the earth atmosphere and potential resources of this unconventional fuel and raw material. Unfortunately, a small number of publications deal with this subject, and the available works mainly deal with the definition of methane resources and methodological approaches to their assessment. These issues are dealt with in the work by V.A. Fedorin and O.V. Taylakov where the rate of methane extraction from the exposed surface of coal seams depending on the gas bearing capacity of the collector and a number of other factors is taken as the methodical basis for determining methane resources in the mined-out area of the mine.

In the work by N.O. Kaledina and D.A. Mescheryakov the solution of the problem involves the need of accounting the dynamics of the collector and filtration properties changes of the worked-out spaces in the course of the deposit development.

In the work by A. D. Ruban and V.S. Zaburdiaev the main focus in assessing the amount of methane emissions in the worked-out areas should be studying gas recovery of coal seams and an actual volume of methane emissions at the development units, rather than geological resources of methane in the mining massif.

The analysis of literature dealing with mine methane resources estimation methods in the fields of the abandoned mines indicates contradictory approaches to the solution of this problem which indicates the need of expanding and deepening studies of this aspect of developing mine methane resources. At this the increase in the level of methane safety in the worked-out areas of the abandoned coal mines, the greening by reducing the mine greenhouse gas emissions into the atmosphere, the growth of the region energy capacity, and the fulfillment of direct international obligations under the Kyoto Protocol make this trend relevant and important for the coal mining units of the Karaganda region.

Analysis of the recent research. The mining processes associated with the formation of clusters and, subsequently, extraction and utilization of coal mine methane from the abandoned mines were handled by specialists from the coal mining countries of Europe back in the $19^{\text {th }}$ century. The first case of utilizing this gas was registered in the United Kingdom in 1846, when the gas allocated for two years was used for lighting purposes. Significant volumes of capturing and utilizing coal mine methane from the abandoned mines were recorded in Germany, Belgium, Poland, France and a number of other countries. So, from the abandoned in 1959 mine "Santa Barbara" (Germany) within 25 years there were extracted 265 million $\mathrm{m}^{3}$ of mine methane. In 19821984 in France 9 million $\mathrm{m}^{3}$ of gas with the methane concentration up to $70 \%$ was mined from the workedout fields of the Nor and Pas de Calais mines, and the volume of extracted coal mine methane in 1985 was 55 million $\mathrm{m}^{3}$. In Australia, from the Balmine that was closed in 1942, within 36 years there were captured 365 million $\mathrm{m}^{3}$ of mine methane with $50-60 \%$ methane and $3 \%$ ethane. From the worked-out area of the Blue Creek mines No. 3, 4, 5 and 7 (USA) at the depth of 500-700 $\mathrm{m}$ with the use of 85 wells there were produced 1.5 billion $\mathrm{m}^{3}$ of high quality gas within 7 years.

But it is impossible to transfer the existing foreign experience of methane extraction from the old developed areas to the mines of the Karaganda basin because of various mining and geological and mining conditions of the mines of foreign countries, as well as the existing legislative and economic base.

Unsolved aspects of the problem. In the field of the stoping impact there are formed a number of zones that differ in the nature and degree of deformation of the enclosing rocks. Among researchers who have studied the process of displacement from the standpoint of protecting buildings and structures on the surface, developing measures to deal with mining impacts, sudden outbursts of coal and gas, preservation of mine workings in the formation of the layers being developed, there is no uniform opinion on the number and size of zones of various stress-strain states.

None of the existing mine methane migration control procedures provides for [1]:

- studying the rock collapse at the abandoned mines to identify man-made methane collectors and the possibility of forming a filtration link to the earth surface;

- taking into account geodynamic zones that can be regarded as additional natural ways of methane migration to the daylight surface.

It is not possible to rank all the criteria for selecting prospective methane recovery units from the workedout spaces of the abandoned coal mines in importance, as in each specific case one or another criterion may turn out to be the most significant and determining. So, for example, one unit can "yield" to another in terms of the area of worked-out fields, in terms of saturation of the man-made collector (the total thickness of the underworked and disturbed by mining operations seams), but it is more promising in view of the later years of working out seams or hydrogeological conditions.

Methane of the abandoned coal mines is mainly considered as an alternative source of energy, therefore research tasks are limited to the issues of its search and extraction based on the existing knowledge of the processes occurring within the mining ditch of the abandoned mine in which it participates.

Thus, at the abandoned mines taken as priority objects under study, there must be found contours of areas that are promising areas for localization of man-made methane and within which there are no migration routes for uncontrolled gas emission, the geodynamic zone impact areas and the anthropogenic filtration link to the earth surface.

Objectives of the article. In Kazakhstan there is little experience in recycling methane from abandoned mines, but given the experience of other countries, one can expect that research in this direction can be very promising. 
If we take into account coal mines that were previously abandoned and those that are to be liquidated in the near future, the total number of potential targets for organizing industrial mining of coalmine methane from the mining bends of liquidated enterprises can significantly increase. The successful development of this industry will be developing a new research method to identify the most probable collectors of gas collectors and their volumes from the position of rock shift and gas dynamics of coal seams.

Presentation of the main research. Mining one coal seam of the suite of adjacent seams leads to redistribution of rock pressure in the rocks enclosing the layer under development and changes in their stress state. The nature and intensity of this change depends on a complex set of natural and mining factors that include the thickness, the angle of the layer inclination, the methane content of the coal seams, the lithological composition, the physical and mechanical properties of the interseam thickness of rocks, the distance of under- and overworked seams from the developed capacity, the method for controlling rock pressure, the speed of moving the breakage face, the length of the lava, the time of advancing the stoping relative to the satellite seams, and others.

In the field of the stoping impact there are formed a number of zones that differ in the nature and degree of deformation of the enclosing rocks. In the field of the stoping impacts on the surrounding massif, when controlling the roof with complete collapse, at least four zones can be distinguished (Fig. 1): collapse, cracks, deflection without breaking continuity and reference pressure.

Under the zone of collapse it is usually understood that such a region is above the stoping within which the layers of the rocks of the immediate roof bending in the direction of the worked-out space, are separated from the overlying layers and collapse onto the soil of the working as unconnected blocks. The rocks lying above

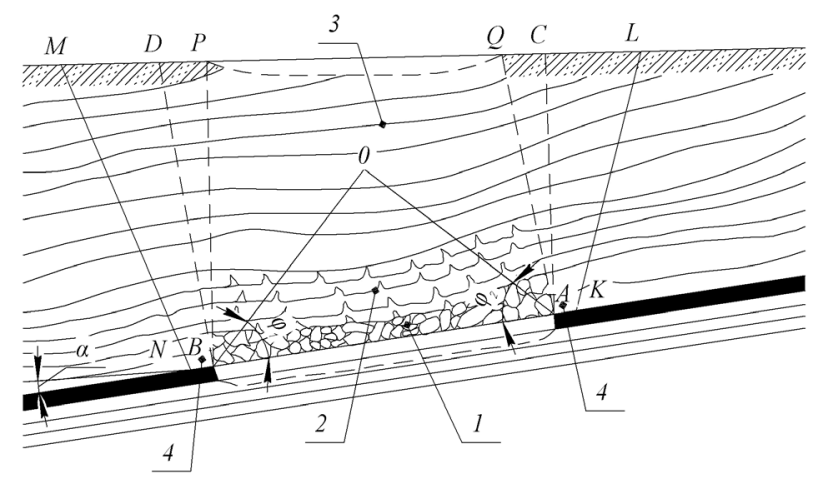

Fig. 1. Zones of the stoping impact on the surrounding massif:

1 - zone of disordered collapse; 2 - zone of cracks; 3 zone of deflection without discontinuity of integrity; 4 reference pressure zone; $A O B$ is the zone of complete normal shifts; $\varphi_{1}$ and $\varphi_{2}$ are the angles of total shifts; MHKL is the region of displacement; $D P$ and $Q C$ are parts of the earth surface where cracks and ruptures are most likely; $N B$ and $A K$ are the reference pressure zone the collapse zone under the impact of rock pressure forces bend, lose continuity, and new natural cracks form in them. Above the zone of crack formation the thickness of the rocks is stratified, and the layers bend without breaking the continuity and formation of cracks.

A zone of increased (reference) pressure is formed around the stope due to hanging and deflecting the rocks above the working in which the rocks are compressed. This zone is characterized by the fact that the mining massif within it is experiencing increased impact of compressing pressure by the normal to stratification compared the rest of the zone. The seam itself and the enclosing rocks are under the impact of the reference pressure. In enclosing rocks the reference pressure impact is somewhat less than that of the coal to be removed in which the noticeable effect of the reference pressure extends $100 \mathrm{~m}$. The maximum reference pressure point is at the distance of 3-6-fold extracting seam thickness from the production boundary [2].

The layers of rocks to be overworked due to the redistribution of rock pressure also undergo changing in the stress-strain state. As a result of manifestation of lateral expansion forces, the rocks of the developed collector are elevated toward the worked-out space, however, the intensity of the displacement process when working out is smaller and occupies lesser depths than when underworking.

The establishment of gas collectors in the under- and overworked zones of the coal seam formation can be made by using geo-mechanical parameters of the rock movement under the impact of the stoping, of which the basic are: boundary angles, maximum subsidence angles, angles of total displacement and subsidence.

The part of the rock massif that has undergone deformations and displacements under the impact of mine workings is called the region of rock shifting, and the part of the earth surface on which shifts and deformations arose is called a shift trough. The boundaries of the shift trough on the earth surface are determined by the boundary angles.

The boundary angles $\beta_{\mathrm{o}}, \gamma_{\mathrm{o}}, \delta_{\mathrm{o}}$ (Figs. 2, 3) are external relative to the worked-out space formed on vertical sections along the main sections of the trough with full work-out by the horizontal line and the lines connecting the production boundaries with the boundary points of the shift trough (Table).

The maximum subsidence angle $O$ is the angle on the side of the seam inclination formed on the vertical section in the main section of the trough across the strike of the formation by a horizontal line and a line connecting the middle of the working with the point of maximum subsidence.

The angles of total displacement are internal angles relative to the worked out space formed on the vertical sections in the main sections of the plane shift trough and the lines connecting the production boundaries with the boundaries of the flat bottom of the trough. There are angles of total shifts: $\varphi_{1}$ at the working lower boundary, $\varphi_{3}$ at the working boundary along the strike.

The maximum subsidence of the earth surface is calculated by the formula 


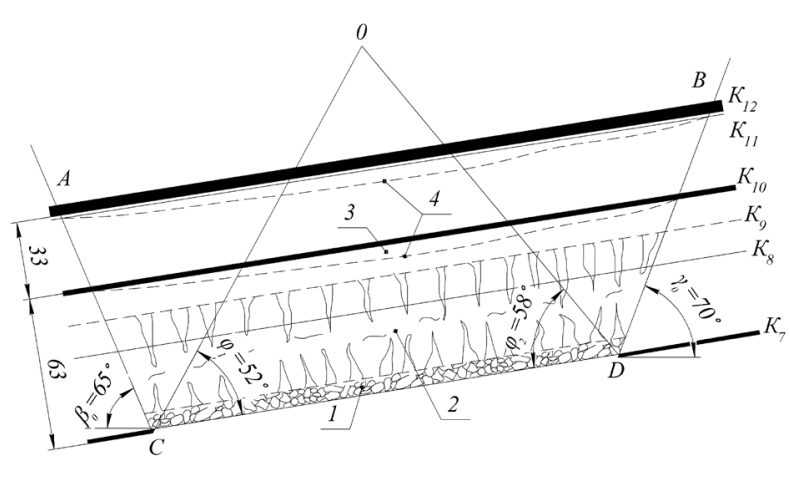

Fig. 2. Rock massif dip displacement:

1 - zone of disordered collapse $h_{0}=6.0 \mathrm{~m} ; 2$ - cracking zone $h_{1}=40 \mathrm{~m} ; 3-$ zone of deflection without breaking continuity of rocks; 4 - cavities of stratification

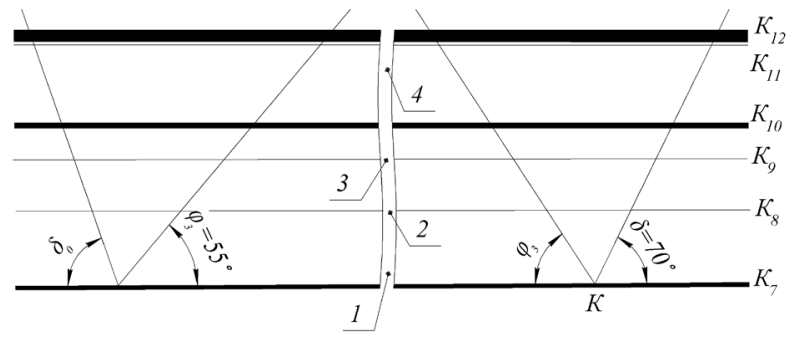

Fig. 3. Rock massif displacement along the strike:

1 - zone of disordered collapse; 2 - cracking zone; 3 zone of deflection without breaking continuity of rocks; $4-$ cavities of stratification

$$
\eta_{\max }=q m \cos \alpha N_{1} N_{2},
$$

where $q=0.75$ for the non-worked thickness; $q=0.85$ for the underworked thickness; $m$ is the worked-out thickness of the seam, m; $N_{1}, N_{2}$ are coefficients defined depending on the lava length ratio to the operation depth and are taken equal to 0.3 .

The process of coal bed underworking leads to a sharp increase in the gas permeability and filtering capacity as a result of partial or complete release of these layers from rock pressure, manifestation of tensile forces, uncovering existing natural (tectonic, endogenous, cleavage) and appearing new (operational) cracks in coal. Partial release of rock pressure increases the amount of underworked and overworked coal seams by $0.1-0.4 \%$ as a result of elastic deformations of rocks, under the impact of which the filtering pores and cracks are opened and expanded which in turn increases the amount of desorbed methane and sharply increases the intensity of gas recovery. With the deflection of underworked and, to a much lesser extent, overworked rock

Table

Numerical values of the shift angles for the Karaganda basin conditions

\begin{tabular}{|c|c|c|c|c|c|c|}
\hline Angle & $\beta_{\mathrm{o}}$ & $\gamma_{\mathrm{o}}$ & $\delta_{\mathrm{o}}$ & $\varphi_{1}$ & $\varphi_{2}$ & $O$ \\
\hline Value & $70^{\circ}-0.6 \alpha$ & $70^{\circ}$ & $70^{\circ}$ & $55^{\circ}-0.4 \alpha$ & $55^{\circ}+0.4 \alpha$ & $90^{\circ}-0.4 \alpha$ \\
\hline
\end{tabular}

${ }^{*} \alpha$ is the seam inclination angle, deg. layers there are formed stratification cavities of rocks which under certain conditions can be filled with gas desorbed from partially discharged coal seams. Most likely is formation of such cavities in the zone of rock deflection without discontinuity of integrity at the contact of layers with different physical and mechanical properties. As a rule, stratification cavities are formed at the contacts between the coal seam and the rock due to the difference in their strength characteristics.

Studies by various authors have shown that the zones of extension of the adjacent layers in the places of rock deflection under and above the worked-out space are manifested at its boundaries. In these zones, there are the most favorable conditions for forming cracks of expansion and voids of stratification of rocks and areas with increased gas permeability and fracturing of coal seams. Determining the position of these zones in relation to the workings is the main task when selecting the parameters of the wells when extracting gas from the abandoned mines. Accumulators of gas can be stopped, preparatory and other open mining workings in closed mines.

Based on the concepts of the mechanisms of coal seismic shift, there was carried out an analysis of forming possible gas collectors for the working conditions of the $K_{7}$ seam at the Industrial unit of the Karaganda ba$\sin$. For this purpose, according to the geological conditions of the coal seams occurrence and the angles of displacement of the coal-bearing stratum, sections were plotted along the strike and across the strike. At this there was considered an option when the lower $K_{7}$ layer was worked out, and on the $K_{10}$ and $K_{12}$ layers there were coal pillars left. In Fig. 3 there are shown sections of the coal-and-rock thickness under study at which the angles and sizes of the displacement zones were determined from the above data. The calculations and analysis show that the height of the disordered collapse zone for the $K_{7}$ seam is $6.0 \mathrm{~m}$, and coal seams and interlayers do not enter it.

In the zone of crack formation with the height of $40 \mathrm{~m}$ there are $K_{8}$ and $K_{9}$ interlayers, from which methane is released into the worked out lava space along the $K_{7}$ formation. The layers $K_{10}, K_{11}$ and $K_{12}$ fall into the zone of the seams deflection without breaking their continuity. The greatest amount of subsidence in the region of the angles of total displacement is confined to the middle of the lava.

The underworked seams $K_{10}$ and $K_{12}$ falling into the region of displacement, are released from the rock pressure and bend toward the worked out space. Since the roof rocks of the layers $K_{10}$ and $K_{12}$ (the coefficient of strength is 5.2 and 4.5 , respectively) is significantly higher than strength of coal seams, at the contacts of layers of the coal bed rock when the layers are bent there are formed stratification cavities. The sources of methane replenishment of the formed cavities can include rocks located in the soil at the distance from the collector multiple to $50-60$ of its thicknesses, and release (desorption) and filtration of methane into the man-made collector can be observed at distances up to $2 \mathrm{~km}$ from the mining front. The sampling rate of mine methane 
from the man-made collector is determined by permeability of its constituent rocks and the rate at which methane replenishes the collector filtration volume through desorption [3].

The spatial parameters of the man-made collector are determined by the coordinates of its shell, the quantitative characteristic of which can be the condition $K<1 \mathrm{mD}$ where $K$ is the coefficient of gas permeability determined by the well-known classification of collector rocks as "practically impenetrable" according to A. A. Khanin. The rock gas content between the cavity and the shell in fact determines the reserves of the deposit, and their permeability determines the expediency of its operation [4].

The process of gas desorption from coal continues until the equilibrium in the dynamic coal-methane system is established at a new level after the process of shifting and restoring the rock pressure ceases. Filling the formed cavities with methane will occur before gas pressure is equalized in the cavity and in the coal seam. The duration of natural methane drainage till the residual methane content is comparable to the total duration of the shift process.

For the conditions of the Karaganda basin, at a speed of $40-60 \mathrm{~m} / \mathrm{month}$, the total duration of the shift is 10-12 months.

In case when the underworked coal seams are connected with the worked-out space, methane is released into the mine workings of the worked out collector. Otherwise, the stratification cavities filled with gas form a gas collector. Formation of gas collectors is most likely with the deflection of released seams in the region limited by internal angles of displacement.

A similar situation is observed in the overworking of coal seams. Underlying soils bending in the direction of the worked-out space, are stratified at the contacts of rocks of various composition with forming voids that are subsequently filled with methane desorbed from the fractured overworked layer. When stresses in the massif exceed the ultimate strength of the overworked rocks, a fault occurs with forming gas-conducting cracks communicating with the worked out space of the developed seam which leads to gas release into the mine workings of the mining unit.

The most active process of methane desorption from the overworked layers occurs when they are located at the distance up to $35 \mathrm{~m}$ from the developed formation. After the collapse of the roof rocks the overworked rocks are loaded with partial overlapping of the gas-conducting cracks, and the process of gas evolution from the superfluous formation fades in time. If faults of the overworked layers do not occur, and they bend toward the worked-out space without breaking continuity, stratification cavities filled with methane appear at the contact of the coal-rock layers.

Thus, as a result of analyzing the mechanism of the underworked and overworked coal seams shifting it is established that the most likely gas collectors from the position of its possible extraction in the liquidated mines can be:

- stratification cavities at the contacts of coal-rock layers falling into the zone of deflection of rocks without breaking the massif discontinuity located under the middle of the mining unit;

- voids formed at the boundaries of the mining units in the region of displacement limited by internal displacement angles;

- stopped preparatory and other open mining workings that have no connection with the earth surface and overlying mine workings.

The studies carried out permitted to develop a model for calculating the volume of gas cavities after the mine liquidation.

The total volume of gas cavities in the worked out space consists of the following quantities

$$
V=V_{1}+V_{2}+V_{3},
$$

where $V$ is the total volume of the cavity within one developed and prepared pillar, $\mathrm{m}^{3} ; V_{1}$ is the volume of cavities formed from the contouring the worked out field mine workings on its boundaries, $\mathrm{m}^{3} ; V_{2}$ is the volume of cavities formed at the contacts of the rock stratification, $\mathrm{m}^{3} ; V_{3}$ is the volume of cavities formed from the left preparatory workings, $\mathrm{m}^{3}$.

The $V_{3}$ value can be determined from the formula

$$
V_{1}=(0.3 \div 0.5) S P
$$

where $S$ is the mean cross section of the contouring workings, $\mathrm{m}^{2} ; \mathrm{P}$ is the perimeter of the worked out space, $\mathrm{m}$.

The $V_{2}$ value is proposed to be determined by the formula

$$
V_{2}=\eta_{\text {avg }} l_{2} l_{1},
$$

where $\eta_{\text {avg }}$ is the mean width of the rock stratification (bend), $\mathrm{m} ; l_{1}$ is the size of the cavity along the strike, $\mathrm{m}$; $l_{2}$ is the size of the cavity across the strike, $\mathrm{m}$.

Since the stratification cavities are formed by the angles of total shifts, the $l_{1}$ and $l_{2}$ values can be found from the expressions

$$
\begin{gathered}
l_{1}=L-2 h_{i} \operatorname{ctg} \varphi_{3} ; \\
l_{2}=l-h_{i}\left(\operatorname{ctg} \varphi_{1}+\operatorname{ctg} \varphi_{2}\right),
\end{gathered}
$$

where $L$ is the length of the mining field along the strike, $\mathrm{m} ; h_{i}$ is the distance along the normal from the seam being developed to the underworked seam, $\mathrm{m} ; l$ is the length of the lava, $\mathrm{m}$.

The mean width of the rock stratification is determined by the formula

$$
\eta_{\text {avg }}=E_{n}-E_{y}
$$

where $E_{n}=f\left(\sigma_{n}\right)$ is the bend of less hard rocks, m; $E_{y}=$ $=f\left(\sigma_{y}\right)$ is the bend of more hard rocks, $\mathrm{m}$.

The value of the maximum subsidence of the earth surface is determined by (1). The volume of voids from the left workings $V_{3}$ can approximately be found by the formula

$$
V_{3}=0.4 S_{b} l_{c}
$$

where $S_{b}$ is the initial cross section of the stopped working, $\mathrm{m}^{2} ; l_{c}$ is the length of the preparatory cul-de-sac, $\mathrm{m}$.

The total volume of the voids at the abandoned mine is 


$$
V_{m}=\sum_{1}^{n}\left(V_{1}+V_{2}\right)+\sum_{1}^{k} V_{3}
$$

where $n$ is the number of worked out extraction columns within the mining field; $k$ is the number of preparatory cul-de-sacs.

As an example below there are considered gas collectors that can be formed when developing the $K_{7}$ "Remarkable" seam. Above the worked out $K_{7}$ seam at the distances from it that are respectively equal to 63 and $99 \mathrm{~m}$, there are $K_{10}$ and $K_{12}$ seams. The length of the mining field is $2000 \mathrm{~m}$, the extractable thickness of the layer is $1.7 \mathrm{~m}$. The length of the lava is $200 \mathrm{~m}$.

To prepare the underlying column, there was driven a conveyor drift with the length of $2000 \mathrm{~m}$ and the crosssectional area of $15 \mathrm{~m}^{2}$. It is required to determine the volume of voidness as a possible gas collector after the mine abandonment.

By formula (2) we determine the volume of cavities formed from the workings that are contouring the mining field

$$
V_{1}=(0.3 \div 0.5) S P=0.4 \times 15 \times 4400=26400 .
$$

By formulas $(3,4)$ we calculate the voids sizes along the strike and across the strike for the underworked seams $K_{10}$ and $K_{12}$ :

a) $K_{10}$ seam

$$
\begin{gathered}
l_{1}=2000 \times 2 \times 63 \times \operatorname{ctg} 55^{\circ}=1912 ; \\
l_{2}=200-63\left(\operatorname{ctg} 52^{\circ}+\operatorname{ctg} 58^{\circ}\right)=111 ;
\end{gathered}
$$

b) $K_{12}$ seam

$$
\begin{aligned}
& l_{1}=2000-2 \times 99 \times 0.7=1861 ; \\
& l_{2}=200-99(0.78+0.63)=60 .
\end{aligned}
$$

The bending value makes

$$
h=0.75 \times 1.7 \times 0.98 \times 0.3 \times 0.3=0.1 .
$$

Then the voids volumes from these seams are equal

$$
\begin{aligned}
& V_{2} K_{10}=0.1 \times 1912 \times 111=21223 ; \\
& V_{2} K_{12}=0.1 \times 1861 \times 60=11166 .
\end{aligned}
$$

The volume of the cavity from the driven conveyor drift will be

$$
V_{3}=0.5 \times 2000 \times 15=15000 .
$$

The total volume of the voids will be

$$
V=26400+21223+11166+15000=73789 .
$$

With the amount of the mined coal in the mining field equal to $2000 \times 200 \times 1.7 \times 1.4=952000 t$, the share of voidness per $1 \mathrm{t}$ of the coal mined will be

$$
V_{v}=\frac{73789}{952000} \times 100=7.8 \text {. }
$$

Thus, the carried out analytical studies and calculations permitted doing the following:
- from the positions of rock shift and gas dynamics of coal seams the most likely gas collectors at the abandoned mines have been established;

- a method for calculating the volume of gas collectors has been proposed;

- the share of voidness in relation to the extracted coal that makes about $8 \%$ has been established.

Conclusions and recommendations for further research. It is most rational to extract methane from the abandoned mines whose geological conditions are confined to large anticlinal and dome folds, where high fracturing of the rocks causes their large permeability and methane flow into the worked out space from the large area. The presence of numerous adjacent seams of coal and its interlayers in the undermined thickness forms prerequisites for a very intensive and sufficiently long emission of methane into the worked out space of mines.

The results obtained for establishing the volumes and location of methane gas collectors are the basis for the development of a feasibility study for methane utilization.

\section{References.}

1. Grinev, V.G., Kuznetsova, L.D., Voloshin, N.I., Sergienko, A. I. and Podrukhin, A.A., 2012. Studying coal mine methane resources of closed coal mines in the Donetsk region Physico-technical problems of mining, 15, p. 135.

2. Drizhd, N. A., Zamaliev, N. M., Ahmatnurov, D. R., Shmidt-Fedotova, I. M. and Mussin, R.A., 2016. State and prospects of methane extraction in the fields of the abandoned coal mines of the Karaganda basin. Monograph. KSTU.

3. Shashenko, A. N., Kukharev, E.V., Gapeyev, S. N. and Yeremenko, A. Yu., 2014. Step-by-step procedure for estimating the parameters of the coal-rock massif as a gas collector. Naukovyi Visnyk Natsionalnoho Hirnychoho Universytetu, 6, pp. 38-45.

4. Shashenko, A. N., Kukharev, E. V., Logunova, A. O. and Eremenko, A. Yu., 2014. Estimating spatial and collector parameters of the anthropogenic gas field by geomechanical characteristics of enclosing coal-bearing massif. Naukovyi Visnyk Natsionalnoho Hirnychoho Universytetu, 1, pp. 33-40.

\section{Встановлення обсягів і місцезнаходження газових колекторів ліквідованих вугільних шаXT}

\section{Р. К. Камаров, Н. М. Замалієв, Д. Р. Ахматнуров, Р. А. Мусін}

Республіканське державне підприємство на правах господарського відання „Карагандинський державний технічний університет“, м. Караганда, Республіка Казахстан, e-mail: ipk-kargtu@kstu.kz; nailzamaliev@mail.ru

Мета. Створення методу дослідження зі встановлення найбільш імовірних порожнин-колекторів газу та їх обсягів з позицій зсовування гірських порід і газової динаміки вугільних пластів. 
Методика. Модель утворення пустот і тріщин, заповнених газом у ліквідованих шахтах, побудована на підставі аналізу гірничо-геологічних і гірничотехнічних умов, а також наявних уявлень щодо механізму зсовування гірських порід у виробленому просторі вугільних шахт.

Результати. У результаті аналізу механізму зсовування підроблюваних і надроблених вугільних пластів встановлені найбільш імовірні місцезнаходження колекторів газу з позиції його можливого видобутку в ліквідованих шахтах. Запропонована модель розрахунку обсягу порожнин газу після ліквідації шахти. Встановлена частка пустотності по відношенню до видобутого вугілля, що становить близько $8 \%$.

Наукова новизна. Забезпечення видобутку метану з ліквідованих шахт шляхом буріння вертикальних свердловин з поверхні пов'язане з вирішенням задачі зі встановлення місця їх залягання, виходячи з розрахунку перетину найбільш імовірних колекторів газу. Модель утворення пустот і тріщин, заповнених газом у ліквідованих шахтах, побудована на підставі аналізу закономірностей, що характеризують процес зсовування гірських порід при очисних роботах в ув'язці зі змінними параметрами газової динаміки вугільних пластів.

Практична значимість. Отримані результати є основою для розробки техніко-економічного обгрунтування утилізації метану ліквідованих шахт, що дозволить залучити до паливно-енергетичного балансу регіону великі ресурси нового енергоносія й поліпшити екологічну обстановку за рахунок скорочення викидів метану до атмосфери.

Ключові слова: метан, залишені запаси, десорбція, колектори газу, видобування метану, промислове використання

\section{Установление объемов и местонахождения газовых коллекторов ликвидированных угольных шахт \\ Р. К. Камаров, Н. М. Замалиев, Д. Р. Ахматнуров, Р.А. Мусин}

Республиканское государственное предприятие на правах хозяйственного ведения „Карагандинский государственный технический университет“, г. Караганда, Республика Казахстан, e-mail: ipk-kargtu@kstu.kz; nailzamaliev@mail.ru
Цель. Создание метода исследования по установлению наиболее вероятных полостей-коллекторов газа и их объемов с позиций сдвижения горных пород и газовой динамики угольных пластов.

Методика. Модель образования пустот и трещин, заполненных газом в ликвидированных шахтах, построена на основании анализа горно-геологических и горнотехнических условий, а также имеющихся представлений о механизме сдвижения горных пород в выработанном пространстве угольных шахт.

Результаты. В результате анализа механизма сдвижения подработанных и надработанных угольных пластов установлены наиболее вероятные местонахождения коллекторов газа с позиции его возможной добычи в ликвидированных шахтах. Предложена модель расчета объема полостей газа после ликвидации шахты. Установлена доля пустотности по отношению к добытому углю, которая составляет около $8 \%$.

Научная новизна. Обеспечение добычи метана из ликвидированных шахт путем бурения вертикальных скважин с поверхности сопряжено с решением задачи по установлению места их заложения, исходя из расчета пересечения наиболее вероятных коллекторов газа. Модель образования пустот и трещин, заполненных газом в ликвидированных шахтах, построена на основании анализа закономерностей, характеризующих процесс сдвижения горных пород при очистных работах в увязке с изменяющимися параметрами газовой динамики угольных пластов.

Практическая значимость. Полученные результаты являются основой для разработки техникоэкономического обоснования утилизации метана ликвидированных шахт, что позволит вовлечь в топливно-энергетический баланс региона большие ресурсы нового энергоносителя и улучшить экологическую обстановку за счет сокращения выбросов метана в атмосферу.

Ключевые слова: метан, оставленные запасы, десорбция, коллекторы газа, извлечение метана, промышленное использование

Рекомендовано до публікації докт. техн. наук T. К. Ісабеком. Дата надходження рукопису 05.12.16. 